\title{
PENGARUH LOVE OF MONEY DAN MACHIAVELLIAN TERHADAP PERSEPSI ETIS MAHASISWA AKUNTANSI (STUDI EMPIRIS PADA MAHASISWA PRODI AKUNTANSI UNIVERSITAS MALIKUSSALEH)
}

\author{
Muhammad Yusra ${ }^{1}$, Chairi Utami ${ }^{2}$ \\ ${ }^{1,2}$ Prodi Akuntansi Fakultas Ekonomi dan Bisnis Universitas Malikussaleh Lhokseumawe \\ myusra@unimal.ac.id
}

\begin{abstract}
This study aims to know the influence of Love Of Money and Machiavellian on the ethical perception of accounting students of Malikussaleh University. The data used is primary data and the sampling method used is Slovin method. The data of this research are obtained by distributing questionnaires to the respondents. The data obtained are then analyzed by using Multiple Linear Regression, Data Quality Test, Classic Assumption Test, Hypothesis Testing, and Coefficient of Determination. The results of this study indicate that simultaneously Machiavellian and Love Of Money have a significant effect on the ethical perception of accounting students of Malikussaleh Universit which is indicated by the $f$-count value of 12,600 . While f-table $(d f 1=k$, $d f 2=n-k-1,5 \%)=3.11$, or in other words $f$-count> f-table. Partially, Love Of Money has a significant effect on the ethical perception of accounting students of Malikussaleh University in which indicated by $t$-count of 3.693 and $T$ table $(n-2,5 \%$ two-sided test $)=1.990$ where $t$-count $>t$ table with a significance value of 0.000 or lower than 0.05. and Machiavellian has a significant effect on the ethical perception of accounting students at -Malikussaleh University which is indicated by $t$-count $=2.583$ and $t$-table $(n-2,5 \%$ two-party test $)=1.990$ where $t$-count $>t$-table with the significance value 0.012 or lower than 0.05 .
\end{abstract}

Keywords: Love of money, machiavellian, and ethical perception.

\section{PENDAHULUAN}

Etika merupakan moral yang berhubungan dengan pengambilan keputusan perilaku yang benar atau salah. Kebutuhan etika akan dirasakan ketika unsur-unsur etis dalam berpendapat. Pendapat seseorang berbeda dengan pendapat orang lain. Oleh karna itu, manusia membutuhkan etika untuk mengetahui apa yang seharusnya dilakukan. Mahasiswa pada dasarnya merupakan subyek atau pelaku di dalam pergerakan pembaharuan yang akan menjadi generasi penerus bangsa. Dan mahasiswa sebagai penerus bangsa seharusnya mampu bertindak untuk membangun bangsa kearah yang lebih baik. Namun, tindakan-tindakan mahasiswa sering kali dihadapkan dengan persoalan sikap yang menimbulkan pelanggaran etis.

Perilaku etis seorang akuntan sangat diperlukan dalam menentukan integritas dan kredibilitas di bidang akuntansi. Hal ini sangat dibutuhan karena profesi akuntan sangat rawan dan dekat dengan kecurangan, yang membuat adanya kecurangan adalah seorang akuntan yang memiliki sifat Love Of Money dan Machiavellian. Contoh kasus yang terjadi di Indonesia pada tahun 2009 yaitu, kasus PT Waskita Karya yang terkait dengan kelebihan pencacatan laba bersih sebesar Rp.500 Milyar. Direksi PT Waskita Karya merekayasa keuangan sejak tahun buku 2004-2008 dengan memasukkan proyeksi pendapatan proyek multi tahun ke depan sebagai pendapatan tahun tertentu.

Kasus seperti PT Waskita Karya dalam akuntan pubik mempengaruhi persepsi pengguna laporan keuangan terhadap reliabilitas laporan keuangan. Dengan adanya kasus tersebut, diperlukan upaya untuk mengembalikan kepercayaan masyarakat terhadap profesi akuntansi. Maka dari itu, pendidikan mengenai etika harus benar-benar diterapkan dan diperhatikan dalam bangku perkuliahan dengan harapan kepada mahasiswa mempunyai karakteristik yang menjungjung tinggi nilai-nilai etika dan menjadi individu 
yang berperilaku etis sebelum memasuki dunia kerja.

Normadewi (2012) berpendapat bahwa mahasiswa akuntansi sekarang adalah para profesional akuntansi di masa depan dengan pendidikan etika yang baik sangat diharapkan dapat menguntungkan profesinya dalam jangka panjang. Karena itu para mahasiswa akuntansi menjadi titik awal dalam meningkatkan persepsi etis terhadap profesi akuntansi. Nilai etika sebaiknya ditanam sedini mungkin untuk menciptakan karakter seseorang.

Salah satu faktor yang mepengaruhi perilaku etis seseorang adalah Kecintaan mahasiswa terhadap uang (Love Of Money). Kecintaan terhadap uang disini berfokus pada penilian seseorang terhadapuang yang diperoleh serta bagaimana cara untuk memperolehnya. Seringkali, tingkat kecintaan mahasiswa terhadap uang akan berpengaruh terhadap persepsi etis seseorang mengenai uang. Machiavelliasme juga salah satu faktor yang dapat menyebabkan seseorang berperilaku tidak etis, Richmond (2001) menemukan bukti bahwa kepribadian individu mempengaruhi perilaku etis. Richmond menginvestigasi hubungan paham Machiavellian yang membentuk tipe kepribadian yang disebut sifat Machiavellian serta pertimbangan etis dengan kecendrungan perilaku individu dalam menghadapi dilema etika.

\section{TINJAUAN PUSTAKA}

\section{Landasan teori}

Teori atribusi mempelajari mengenai proses bagaimana seseorang menginterpretasikan suatu peristiwa, alasan, atau sebab perilakunya. Lubis (2010: 90) dalam bukunya "akuntansi keperilakuan", menyatakan bahwa teori atribusi dikembangkan oleh Fritz Heider. Teori ini menjelaskan mengenai bagaimana cara menentukan sumber, penyebab atau motif perilaku seseorang. Sarwono (Darwati, 2015) mengatakan Heider percaya, bahwa orang seperti ilmuwan amatir, berusaha untuk mengerti tingkah laku orang lain dengan mengumpulkan dan memadukan potongan-potongan informasi sampai mereka tiba-tiba pada sebuah penjelasan masuk akal tentang sebab-sebab orang lain bertingkah laku tertentu.

\section{Etika}

Menurut Lubis (2011) Sikap adalah suatu hal yang mempelajari mengenai seluruh tendensi tindakan, baik yang menguntungkan maupun yang kurang menguntungkan, tujuan manusia, objek, gagasan, atau situasi. Istilah objek dalam sikap digunakan untuk memasukkan semua objek yang mengarah pada reaksi seseorang. Definisi sikap adalah suatu tendensi atau kecenderungan dalam menjawab atau merespons, dan bukan dalam menanggapi dirinya sendiri.

\section{Persepsi Etis}

\begin{tabular}{l}
\multicolumn{2}{c}{ Persepsi etis diartikan } & sebagai \\
pandangan seseorang dalam melihat \\
kecurangan akuntansi yang terjadi. \\
Berdasarkan faktor-faktor memengaruhi \\
persepsi seseorang berkaitan dengan variabel \\
independen yang terdapat dalam penelitian \\
ini (Robbins dan Judge, 2007).
\end{tabular}

\section{Love of Money}

Pradanti (2014) mengemukakan Love Of Money adalah orang yang menganggap uang sebagai hal yang sangat penting, mereka akan melakukan segala macam cara untuk mendapatkan uang, termasuk jalan pintas seperti berbuat curang. Namun, Love Of Money juga memberikan dampak positif yaitu memberikan motivasi untuk bekerja lebih giat, sehingga dapat dihormati dalam sebuah komunitas, serta menjadi tolak ukur keberhasilan yang mereka capai.

\section{Machiavellian}

Puspitasari (2012) menyatakan sifat Machiavellian merupakan sifat yang memiliki dampak buruk pada profesi akuntan karena sifat Machiavellian memiliki sikap manipulatif. Sifat tersebut akan menyebabkan menurunnya kepercayaan terhadap profesional akuntan karena mengabaikan pentingnya integritas dan kejujuran dalam mencapai tujuan, sehingga pada akhirnya akan berdampak pada kepercayaan masyarakat terhadap profesionalis akuntan.

\section{Penelitian Terdahulu}

Penelitian-penelitian sebelumnya sangat berperan dalam penelitian ini. Berikut 
ini adalah beberapa penelitian terdahulu yang dijadikan sumber referensi bagi peneliti dalam melakukan penelitian:

1. Penelitian dari Toriq Ibnu Aziz berjudul "Pengaruh Love Of Money dan Machiavellian Terhadap Persepsi Etis Mahasiswa Akuntansi". menunjukkan bahwa Love Of Money berpengaruh negatif signifikan terhadap persepsi etis mahasiswa. Kecintaan seseorang pada uang dapat menunjukkan tujuan hidupnya hanya sekedar mencari materi atau uang saja, dan akan berusaha untuk memperoleh uang dan membelanjakannya sesuai dengan keinginan. Bahkan cara dalam mencari uang dengan yang tidak benar atau tidak sesuai dengan etika. Machiavellian menunjukkan bahwa semakin tinggi memiliki sifat Machiavellian maka semakin mungkin untuk berperilaku tidak etis, dan semakin tinggi persepsi etis seseorang maka dia akan semakin berperilaku etis.

2. Penelitian Kelly Ann Richmond (2001) dengan judul "Ethical Reasioning, Machiavellian Behaviour, and Gender: The Impact On Accounting Students Ethical Decision Making”. Hasil penelitian ini menunjukkan bahwa pertimbangan etis secara signifikan berpengaruh dengan pegambilan keputusan etis jika dilema etis dialami oleh orang lain, tetapi tidak ada berpengaruh ketika dilema etis dihadapi diri sendiri.

Perilaku Machiavellian secara signifikan berpengaruh dengan pengambilan keputusan etis jika dilema etis didalam diri sendri, tetapi tidak berpengaruh ketika diema etis dihadapi orang lain. Gender tidak berpengaruh secara signifikan terhadap perbuatan keputusan etis baik ketika dilema etis dihadapi orang lain ataupun diri sendiri.

3. Penelitian yang dilakukan Damar Septa Prabowo (2012) dengan judul "Analisis Pengaruh Paham Machiavellianisme Dan Love Of Money Terhadap Persepsi Etis Akuntansi Tingkat Akhir Dikota Semarang". Hasil yang didapat dalam penelitian ini kedua variabel independen yaitu Love Of Money dan
Machiavellian secara signifikan mempengaruhi variabel dependen yaitu Persepsi etis mahasiswa akuntansi. Teori harapan dapat digunakan untuk memperkirakan persepsi etis mahasiswa akuntansi dalam kaitannya dengan tingkat Love of Money dan Machavellian dengan cara mengidentifikasi hal-hal apa yang akan diperoleh apabila mahasiswa meningkatkan kecintaannya terhadap uang dan berperilaku Machiavellian tanpa mengutamakan tindakan etis dalam menjalankan pekerjaannya dan apakah hasil yang diperoleh dengan aspek tersebut mampu memuaskan individu.

4. Penelitian yang dilakukan Berlin Normadewi pada tahun 2012 yang berjudul "Analisis Pengaruh Jenis Kelamin dan Tingkat Pendidikan terhadap Persepsi Etika Mahasiswa Akuntansi dengan Love Of Money sebagai variabel Intervening". Hasil dari penelitian ini menunjukkan bahwa jenis kelamin tidak mempunyai hubungan dengan Love Of Money mahasiswa akuntansi dan persepsi mereka serta tingkat pendidikan berpengaruh terhadap Love Of Money dan persepsi etis mereka. Pengaruh hubungan langsung antara tingkat pendidikan dengan persepsi etis mahasiswa akuntansi lebih besar daripada pengaruh Love Of Money.

\section{Kerangka Konseptual}

Konsep Love Of Money sangat erat kaitannya dengan konsep ketamakan, sehingga orang yang mempunyai tingkat Love Of Money yang tinggi, maka ia akan cenderung mempunyai sifat tamak dan mempunyai sifat yang berlebihanakan kecintaannya terhadap uang. Ketamakan merupakan perilaku tidak etis, sehingga seseorang yang mempunyai tingkat Love of Money yang tinggi cenderung berperilaku tidak etis.

Kepribadian $r$ Machiavellian
mempunyai kecendrungan $r$ untuk
memanipulasi orang lain, sangat rendah
penghargaannya pada orang lain. Kualitas
penting dari akuntan adalah untuk menjaga
tingkat integritas dan kemampuan membuat
keputusan etis dengan tepat.




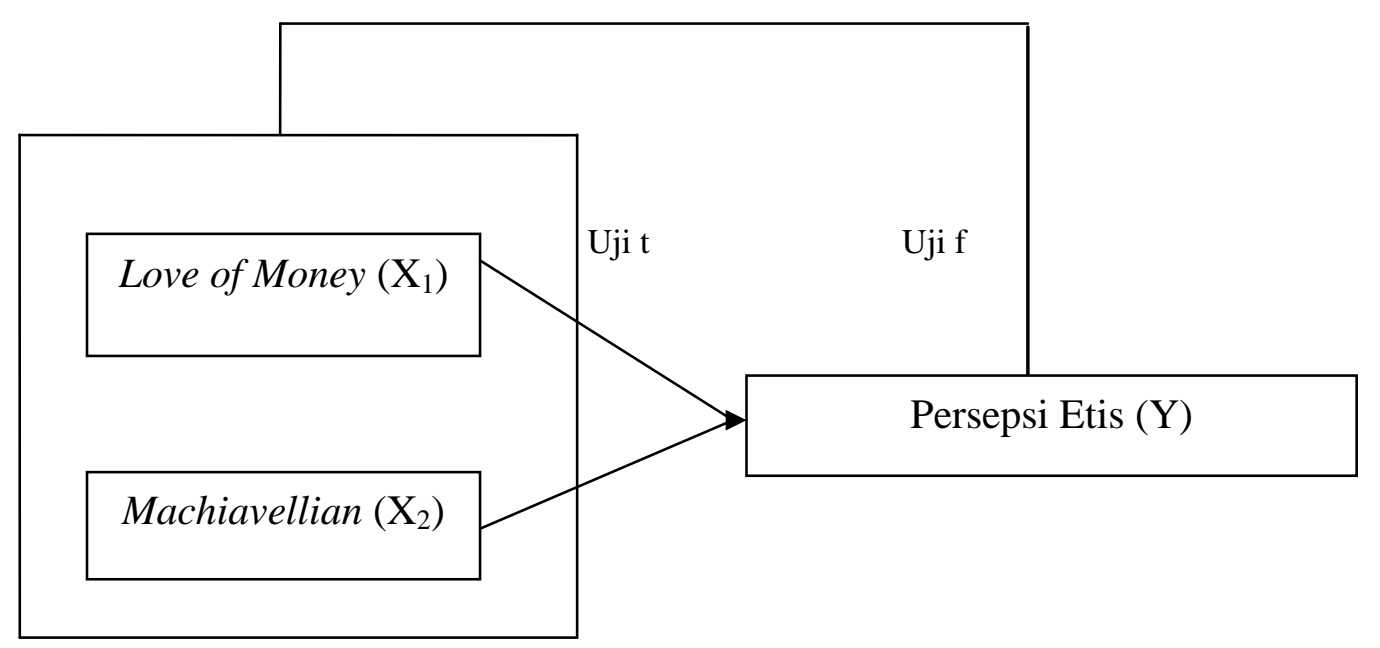

Gambar 1 Kerangka Konseptual

\section{METODOLOGI PENELITIAN}

\section{Objek Penelitian}

Objek dalam penelitian ini adalah Mahasiswa Prodi Akuntansi angkatan 2014 dan 2015 Fakultas Ekonomi dan Bisnis Universitas Malikussaleh.

\section{Populasi dan Sampel}

populasi penelitian adalah mahasiswa aktif Prodi Akuntansi Fakultas Ekonomi dan Bisnis Universitas Malikussaleh angkatan 2014, dan 2015, berjumlah 457 mahasiswa, yang yang telah mengambil matakuliah Etika Bisnis, Pengantar Akuntansi, Akuntansi Keuangan, Pengauditan I, Pengauditan II, Akuntansi Biaya, Akuntansi Perpajakan, Perpajakan, Akuntansi Manajemen, Akuntansi Lanjutan 1, dan Akuntansi Lanjutan II. Hal ini dikarenakan mahasiswa yang telah mengambil matakuliah tersebut telah memiliki ilmu dan pemahaman tentang etika dan akuntansi.

Jumlah anggota sampel di tentukan melalui Pengambilan batas minimum sampel dapat dapat di ketahui dengan menggunakan rumus yang di kemukakan Yamane, sebagai berikut:

$$
\mathrm{n}=\frac{N}{N: d^{2}+1}
$$

dimana :

$\mathrm{n}=$ Jumlah sampel

$\mathrm{N}=$ Jumlah populasi $\mathrm{d}=$ tingkat depresiasi yang di harapkan tidak menyimpang dari $10 \%$ $\mathrm{n}=\frac{N}{N: d^{2}+1}=\frac{457}{457(0,1)^{2}+1}=\frac{457}{5,57}=82,04 \approx$

82 Orang.

proporsional Random Sampling dengan rumus:

$$
\mathrm{ni}=\frac{N i}{N} \cdot n
$$

ni = Jumlah anggota sampel menurut stratum $\mathrm{n}=$ Jumlah anggota sampel seluruhnya

$\mathrm{Ni}=$ Jumalah anggota populasi menurut stratum

$\mathrm{N}=$ Jumlah anggota populasi seluruhnya

Maka jumlah anggota sampel:

$$
\begin{aligned}
& 2014=\frac{178}{457} \cdot 82=31,93 \approx 32 \text { Orang } \\
& 2015=\frac{279}{457} \cdot 82=50,06 \approx 50 \text { Orang }
\end{aligned}
$$

\section{Teknik Pengumpulan Data}

Teknik pengumpulan data yang digunakan dalam penelitian ini adalah dengan menggunakan kuesioner. Penyebaran dan pengumpulan kuesioner dilakukan dengan cara memberikan secara langsung kuesioner ke mahasiswa ekonomi jurusan akuntansi angkatan 2014 dan 2015 Universitas Malikussaleh.

\section{Metode Analisis Data}

Metode analisa data yang digunakan meliputi: Uji kualitas data, uji asumsi klasik, dan uji regresi linier berganda. Uji kualitas data digunakan untuk 
melihat pertanyaan dari kuisoner yang disebarkan atas kelayakan pertanyaannya. Uji asumsi klasik dilakukan untuk mengetahui apakah data sampel yang diolah dapat benar-benar valid dan mewakili populasi secara keseluruhan. Sedangkan uji regresi linier berganda bertujuan untuk menguji dan menganalisa secara parsial dan simultan. Model persamaan regresi yang dapat diperoleh dalam analisis adalah:

$$
\mathbf{Y}=\boldsymbol{\alpha}+\mathbf{b} 1 \mathbf{X} 1+\mathbf{b} 2 \mathrm{X} 2+\mathbf{e}
$$

Keterangan:

$$
\begin{aligned}
& \alpha: \text { Konstanta } \\
& \mathrm{b}: \text { Koefisien Linear Berganda } \\
& \mathrm{Y}: \text { Persepsi Etis } \\
& \mathrm{X} 1: \text { Love of Money } \\
& \mathrm{X} 2: \text { Machiavellian } \\
& \text { ei }: \text { Faktor Penganggu }
\end{aligned}
$$

\section{HASIL PENELITIAN DAN PEMBAHASAN}

\section{Uji Validitas}

Menurut Ghozali (2013: 52), uji validitas digunakan untuk mengukur sah atau validnya sebuah kuesioner. Suatu kuesioner mampu mengungkapkan sesuatu yang diukur oleh kuesioner, pengujian dilakukan secara statistik, manual atau bantuan komputer. Perhitungannya didasarkan pada perbandingan $r$ hitung dan $r$ tabel Apabila $r$ hitung lebih besar dari $r$ tabel dan nilainya positif (pada tarif signifikan 5\% atau 0,05) maka data bisa dikatakan valid. Pengujian dilakukan dengan bantuan SPSS v 17.angka pada $r$ tabel $=0,242$ (uji dua sisi). Untuk lebih jelas dapat dilihat pada tabel 4.8 berikut ini.

Jadi $\mathrm{r}_{\text {hasil }}$ untuk tiap item bisa dilihat pada kolom corrected item-total correlation, dan untuk degree of freedom $(\mathrm{df})=\mathrm{n}-2$,

\begin{tabular}{|c|c|c|c|c|}
\hline No & Butir Pertanyaan & $\begin{array}{c}\text { corrected item-total } \\
\text { correlation }\end{array}$ & $R$ tabel & Keterangan \\
\hline 1 & 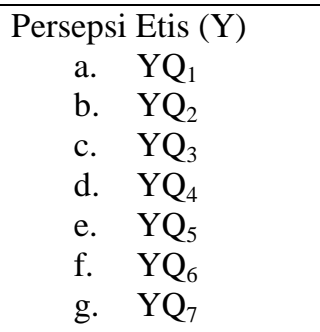 & $\begin{array}{l}0,266 \\
0,363 \\
0,506 \\
0,264 \\
0,461 \\
0,413 \\
0,384\end{array}$ & $\begin{array}{l}0,217 \\
0,217 \\
0,217 \\
0,217 \\
0,217 \\
0,217 \\
0,217\end{array}$ & $\begin{array}{l}\text { Valid } \\
\text { Valid } \\
\text { Valid } \\
\text { Valid } \\
\text { Valid } \\
\text { Valid } \\
\text { Valid }\end{array}$ \\
\hline 2 & 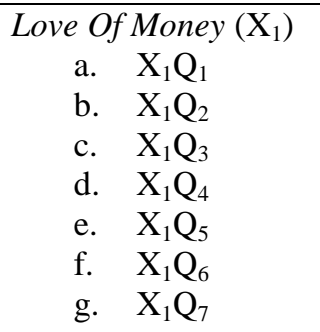 & $\begin{array}{l}0,450 \\
0,506 \\
0,438 \\
0,449 \\
0,555 \\
0,543 \\
0,377\end{array}$ & $\begin{array}{l}0,217 \\
0,217 \\
0,217 \\
0,217 \\
0,217 \\
0,217 \\
0,217\end{array}$ & $\begin{array}{l}\text { Valid } \\
\text { Valid } \\
\text { Valid } \\
\text { Valid } \\
\text { Valid } \\
\text { Valid } \\
\text { Valid }\end{array}$ \\
\hline 3 & $\begin{array}{cc}\text { Machiavellian } & \left(\mathrm{X}_{2}\right) \\
\begin{array}{cc}\text { a. } & \mathrm{X}_{2} \mathrm{Q}_{1} \\
\text { b. } & \mathrm{X}_{2} \mathrm{Q}_{2} \\
\text { c. } & \mathrm{X}_{2} \mathrm{Q}_{3} \\
\text { d. } & \mathrm{X}_{2} \mathrm{Q}_{4} \\
\text { e. } & \mathrm{X}_{2} \mathrm{Q}_{5} \\
\text { f. } & \mathrm{X}_{2} \mathrm{Q}_{6} \\
\text { g. } & \mathrm{X}_{2} \mathrm{Q}_{7}\end{array}\end{array}$ & $\begin{array}{l}0,414 \\
0,354 \\
0,589 \\
0.485 \\
0,444 \\
0,566 \\
0,295\end{array}$ & $\begin{array}{l}0,217 \\
0,217 \\
0,217 \\
0,217 \\
0,217 \\
0,217 \\
0,217\end{array}$ & $\begin{array}{l}\text { Valid } \\
\text { Valid } \\
\text { Valid } \\
\text { Valid } \\
\text { Valid } \\
\text { Valid } \\
\text { Valid }\end{array}$ \\
\hline
\end{tabular}
dimana $\mathrm{n}$ adalah jumlah sampel (Ghozali, 2013), berarti $\mathrm{df}=82-2=80$, dengan tingkat signifikansi 5\% didapat angka pada $\mathrm{r}$ tabel $=$ 0,217 (uji dua sisi). Untuk lebih jelas dapat dilihat pada tabel 1 berikut ini:

Tabel.1 Hasil Pengujian Validitas

Sumber: Hasil Penelitian, 2018 
Berdasarkan Tabel 1 di atas, terlihat bahwa dari 21 (dua puluh satu) butir pertanyaan, semua mempunyai $r_{\text {hasil }}$ di atas $r_{\text {tabel }}(0,217)$. Hasil uji validitas menunjukkan bahwa seluruh butir pertanyaan angket pada 2 variabel independen dan variabel dependen dinyatakan valid.

\section{Uji Reliabilitas}

Uji reliabilitas digunakan untuk mengukur suatu kuesioner yang merupakan indikator dari variabel atau kontruk. Suatu kuesioner dikatakan reliabel jika jawaban seseorang terhadap pertanyaan adalah konsisten atau stabil. Pengujian reliabilitas dalam penelitian ini adalah dengan menggunakan rumus alpha. Menurut Ghozali (2013: 47), adalah: (1). Jika nilai hasil croanbach alpha >0,60, maka butir atau variabel tersebut reliabel; (2). Jika nilai hasil croanbach alpha $<0,60$, maka butir atau variabel tersebut tidak reliabel.

Berikut ini adalah tabel hasil pengujian reliabilitas:

Tabel.2 Hasil Pengujian Reliabilitas

\begin{tabular}{|l|l|l|l|}
\hline Variabel & Alpha & Batasan & Keterangan \\
\hline Love Of Money $\left(X_{1}\right)$ & 0,688 & 0,60 & Reliabel \\
\hline Machiavellian $\left(X_{2}\right)$ & 0,699 & 0,60 & Reliabel \\
\hline Persepsi Etis $(\mathrm{Y})$ & 0,668 & 0,60 & Reliabel \\
\hline
\end{tabular}

Sumber: data primer, 2018 (diolah)

Berdasarkan Tabel 2 di atas terlihat bahwa hasil croanbach alpha dari variabel Love Of Money $\left(\mathrm{X}_{1}\right)$ yaitu sebesar 0,688 > 0,60, Machiavellian $\left(\mathrm{X}_{2}\right)$ sebesar 0,699> 0,60, dan Persepsi Etis (Y) sebesar 0,668 > 0,60 . Dengan demikian semua butir-butir variabel pertanyaan di atas adalah reliabel.

\section{Uji Asumsi Klasik}

\section{Uji Normalitas}

Uji normalitas bertujuan untuk menguji apakah dalam suatu model regresi linear berganda variabel bebas dan variabel terikat keduanya mempunyai distribusi normal atau tidak. Model regresi yang baik adalah memiliki distribusi data normal atau mendekati normal. Uji normalitas dapat diketahui dengan melihat normal probability plot. Distribusi normal akan membentuk satu garis lurus diagonal dan ploting data residual akan dibandingkan dengan garis diagonal. Jika distribusi data residual normal, maka titik-titik yang menggambarkan data akan mengikuti garis diagonalnya. Uji normalitas data dapat dilihat pada gambar 2 berikut:

\section{Dependent Variable: $Y$}

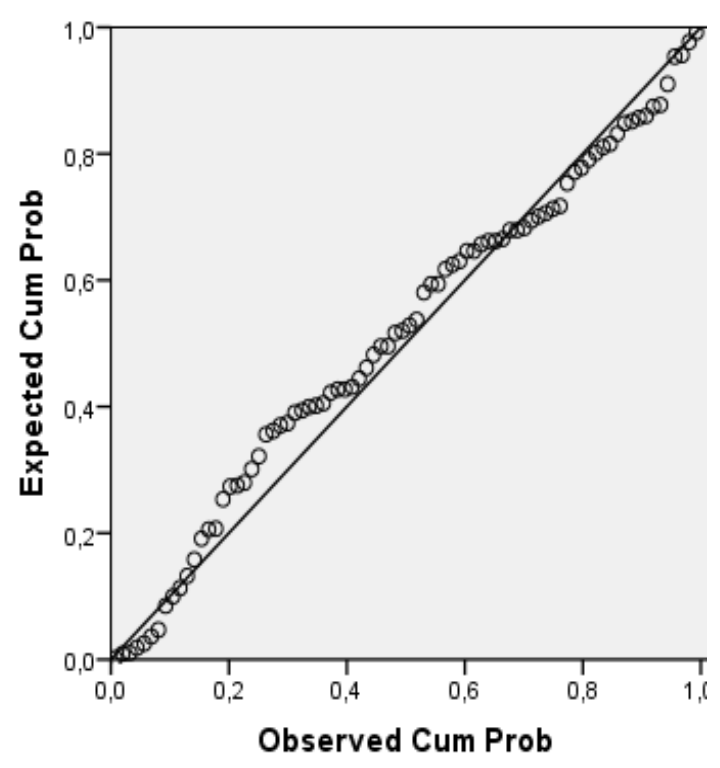

Berdasarkan Gambar 2 grafik normal plot, menunjukkan bahwa model regresi layak dipakai dalam penelitian ini karena grafik normal plot terlihat titik-titik menyebar disekitar garis diagonal serta penyebaran mengikuti arah garis diagonal menunjukkan pola distribusi normal, sehingga model regresi memenuhi asumsi normalitas. 


\section{Uji Multikolienaritas}

Untuk menguji apakah terdapat interkorelasi yang sempurna diantara beberapa variabel bebas digunakan dalam persamaan regresi digunakan uji multikolinieritas. Uji multikoliniertas menggunakan nilai tolerance dan VIF (varian inflation factor). Berdasarkan hasil perhitungan dengan SPSS versi 17.0 didapatkan hasil sebagai berikut:

Tabel .3 Hasil Pengujian Multikolinieritas (Pada Bagian Coefficients)

\begin{tabular}{|l|l|l|l|}
\hline \multirow{2}{*}{ Variabel } & \multicolumn{2}{|c|}{ Collinearity Statistic } & \multirow{2}{*}{ Keterangan } \\
\cline { 2 - 4 } & \multicolumn{2}{|c|}{ Tolerance } & \multicolumn{2}{|c|}{ VIF } & \\
\hline $\mathrm{X}_{1}$ & 0,979 & 1,022 & Tidak ada multikolinearitas \\
$\mathrm{X}_{2}$ & 0,979 & 1,022 & Tidak ada multikolinearitas \\
& & & \\
\hline
\end{tabular}

Sumber: Hasil Penelitian, 2018

Dari Tabel.3 di atas terlihat bahwa nilai tolerance dan nilai VIF menunjukkan tidak ada multikolinearitas, hal ini terlihat dari nilai VIF, untuk $\mathrm{X}_{1}$ sebesar 1,022 kurang dari 10 dan tolarance $\mathrm{X}_{1}$ sebesar 0,979 diatas 0,10 . Untuk $\mathrm{X}_{2}$ sebesar 1,022 kurang dari 10 dan tolarance $\mathrm{X}_{2}$ sebesar 0,979 diatas 0,10. Dan ini berarti tidak ada korelasi antar variabel bebas sehingga menandakan bahwa model regresi yang dihasilkan tidak terjadi multikolinieritas. .

\section{Analisis Regresi Linier Berganda}

Penelitian ini bertujuan untuk mengetahui pengaruh Love Of Money dan Machiavellian terhadap Persepsi Etis Mahasiswa Akuntansi di Universitas Malikussaleh. Oleh karena itu digunakan analisis regresi linear berganda untuk menganalisis pengaruhnya. Hasil analisis linear berganda dengan program SPSS versi 22 diperoleh sebagai berikut:

Tabel.4 Hasil Analisis Regresi Linear Berganda Pengaruh Love Of Money dan Machiavellian Terhadap Persepsi Etis Maahasiswa Akuntansi

\begin{tabular}{|c|c|c|c|}
\hline Variabel & Koefisien & T hitung & Sig \\
\hline Constant & 9,790 & 3,889 & 0,000 \\
$\mathrm{X}_{1}$ & 0,345 & 3,876 & 0,000 \\
$\mathrm{X}_{2}$ & 0,229 & 3,010 & 0,004 \\
& & & \\
\hline $\mathrm{DF}=82-2=80$ & $\mathrm{R}=0,492$ & $\mathrm{~T}_{\text {tabel }}=1,999$ & $\mathrm{~F}_{\text {hitung }}=14.053$ \\
& $\mathrm{R}^{2}=0,242$ & & $\mathrm{~F}_{\text {tabel }}=3,11$ \\
\hline
\end{tabular}

Sumber: Hasil Penelitian, 2018

Berdasarkan Tabel 4 di atas dapat dilihat koefisien dari masing-masing variabel dan konstanta yang menjadi observasi dalam penelitian ini adalah koefisien $\left(X_{1}\right)$ 0,345, koefisien $\left(X_{2}\right)$ 0,229, dan konstanta 9,790. Hal ini berarti variabel independen berpengaruh terhadap persepsi etis mahasiswa akuntansi di Universitas Malikussaleh. Secara persamaan dapat ditulis sebagai berikut:

$$
Y=9,790+0,345 X_{1}+0,229 X_{2}+e i
$$

\section{Uji Signifikan Parsial (Uji t)}

Pengujian ini dilakukan dengan ketentuan jika $t_{\text {hitung }}>t_{\text {tabel }}$ pada $\alpha=$ 0.05 maka hipotesis diterima atau dengan kata lain terdapat pengaruh yang signifikan antara satu variabel independen terhadap variabel dependen. 
Tabel 5 Hasil Uji t

\begin{tabular}{|c|c|c|c|c|c|c|c|c|}
\hline \multirow{2}{*}{\multicolumn{2}{|c|}{ Model }} & \multicolumn{2}{|c|}{$\begin{array}{l}\text { Unstandardized } \\
\text { Coefficients }\end{array}$} & \multirow{2}{*}{$\begin{array}{l}\text { Standardized } \\
\text { Coefficients } \\
\text { Beta }\end{array}$} & \multirow[b]{2}{*}{$\mathrm{T}$} & \multirow[b]{2}{*}{ Sig. } & \multicolumn{2}{|c|}{$\begin{array}{l}\text { Collinearity } \\
\text { Statistics }\end{array}$} \\
\hline & & B & Std. Error & & & & Tolerance & VIF \\
\hline \multirow[t]{3}{*}{1} & (Constant) & 9,790 & 2,517 & & 3,889 &, 000 & & \\
\hline & $\mathrm{X} 1$ & 345 & 089 & 379, & 3,876 & ,000 & 979 & 1,022 \\
\hline & $\mathrm{X} 2$ & 229 & ,076 & 294 & 3,010 & ,004 & ,979 & 1,022 \\
\hline
\end{tabular}

Sumber: Hasil Penelitian, 2018

Berdasarkan Tabel 5 diatas dapat dilihat bahwa nilai $t_{\text {hitung }}$ untuk Love of money $\left(\mathrm{X}_{1}\right)$ sebesar 3,876, dan untuk Machiavellian $\left(\mathrm{X}_{2}\right)$ sebesar 3,010. Untuk mengetahui tingkat signifikansi secara parsial pada tingkat kepercayaan $100 \%$ pengujian hipotesis dengan uji t dilakukan dengan membandingkan antara thitung dengan ttabel. Sebagai berikut:

Pembuktian hipotesis variabel Love of Money $\left(\mathrm{X}_{1}\right)$

Secara parsial (uji t) yang diperoleh dari nilai $\mathrm{T}_{\text {hitung }}$ pada persamaan regresi linear berganda menyatakan bahwa Love of money berpengaruh signifikan (nyata) terhadap Persepsi etis, dikarenakan $\mathrm{T}_{\text {hitung }}$ sebesar 3,876 dan $\mathrm{T}_{\text {tabel (n-2, 5\% uji dua pihak) }}=$
1,990 di mana Thitung > Ttabel dengan nilai signifikansi 0,000 dibawah 0,05 . Sehingga hipotesis pertama $\left(\mathrm{H}_{1}\right)$ diterima.

Pembuktian hipotesis variabel Machiavellian $\left(\mathrm{X}_{2}\right)$

Secara parsial (uji t) yang diperoleh dari nilai $\mathrm{T}_{\text {hitung }}$ pada persamaan regresi linear berganda menyatakan bahwa Machiavellian berpengaruh secara signifikan (nyata) terhadap Persepsi etis, dikarenakan $\mathrm{T}_{\text {hitung }}$ sebesar 3,010 dan $\mathrm{T}_{\text {tabel (n-2, 5\% uji dua pihak) }}$ $=1,990$ di mana $T_{\text {hitung }}>T_{\text {tabel }}$ dengan nilai signifikansi 0,004 dibawah 0,05. Sehingga hipotesis kedua $\left(\mathrm{H}_{2}\right)$ diterima.

\section{Uji Hipotesis Secara Simultan (UjiF)}

Tabel 6 Hasil Uji F

\begin{tabular}{|r|r|r|r|r|r|}
\hline \multicolumn{1}{|c|}{ Model } & Sum of Squares & Df & Mean Square & F & Sig. \\
\hline $1 \quad$ Regression & 332,687 & 2 & 166,343 & 14,053 &, $000^{\mathrm{a}}$ \\
Residual & 935,118 & 79 & 11,837 & & \\
Total & 1267,805 & 81 & & & \\
\hline
\end{tabular}

Sumber: Hasil Penelitian, 2018

Berdasarkan Tabel 6 di atas dapat dilihat bahwa nilai $F_{\text {hitung }}$ sebesar 14,053. sedangkan $\mathrm{F}_{\text {tabel }}$ pada tingkat kepercayaan $100 \%$ diperoleh $\mathrm{F}_{\text {tabel(df2= } \mathrm{n}-\mathrm{k}-1,5 \%)}=3,11$, atau dengan kata lain $F_{\text {hitung }}>F_{\text {tabel }}$. Dan juga dapat dilihat dari sig $0,000<0,05$. Pengujian hipotesis dengan uji $\mathrm{F}$ dilakukan dengan membandingkan antara Fhitung dengan Ftabel, dan nilai signifikansinya. Dengan demikian berarti secara simultan variabel Love of money $\left(\mathrm{X}_{1}\right)$, dan Machiavellian $\left(\mathrm{X}_{2}\right)$, berpengaruh secara signifikan terhadap Persepsi etis (Y) pada mahasiswa akuntansi di Universitas Malikussaleh. Sehingga hipotesis ketiga $\left(\mathrm{H}_{3}\right)$ diterima.

\section{Uji Koefisien Determinasi}

Tujuan penelitian ini adalah untuk menguji tingkat keeratan atau keterikatan antar variabel dependen dan variabel independen yang bisa dilihat dari besarnya nilai koefisien determinasi ( $R$ square). Nilai koefisien determinasi adalah antara nol dan satu (Ghozali, 2013:97). Nilai $\mathrm{R}^{2}$ yang kecil berarti kemampuan variabel- variabel independen dalam menjelaskan variabel dependen amat terbatas. Nilai yang 
mendekati satu berarti variabel-variabel independen memberikan hampir semua informasi yang dibutuhkan untuk memprediksi variasi variabel independen.

Tabel 7 Koefisien Determinasi

\begin{tabular}{|l|r|r|r|l|}
\hline Model & & & & \\
R & & R Square & Adjusted R Square & $\begin{array}{l}\text { Std. Error of the } \\
\text { Estimate }\end{array}$ \\
\hline 1 &, $512^{\mathrm{a}}$ &, 262 &, 244 & 3,44049 \\
\hline
\end{tabular}

Sumber: data Primer, 2018 (Diolah)

Berdasarkan hasil perhitungan dalam tabel 7 nilai koefisien determinasi ( $R$ Square) sebesar 0,244 artinya variabilitas dari variabel dependen dapat dijelaskan oleh variabilitas dari variabel independen sebesar $24 \%$ sedangkan sisanya sebesar $76 \%$ dijelaskan oleh variabel lainnya yang tidak di teliti atau tidak masuk dalam model regresi.

\section{PENUTUP}

\section{Kesimpulan}

Berdasarkan pengujian dan hasil penelitian yang telah dilakukan mengenai pengaruh Love Of Money dan Machiavellian terhadap Persepsi etis Mahasiswa Akuntansi di Universitas Malikussaleh. Maka peneliti dapat mengambil kesimpulan sebagai berikut:

1. Variabel Love of Money memiliki nilai sebesar 3,876 $>\mathrm{t}_{\text {table }} 1.990$ dengan nilai signifikansi $0.000<0,05$. Hal ini menunjukkan bahwa Love Of Money berpengaruh signifikan terhadap Persepsi etis Mahasiswa Akuntansi di Universitas Malikussaleh. Hal ini menujukkan bahwa semakin tinggi sifat Love of money mahasiswa tersebut, maka semakin rendah Persepsi etis.

2. Variabel Machiavellian memiliki nilai thitung sebesar 3,010 $>\mathrm{t}_{\text {table }} 1.990$ dengan nilai signifikansi $0,004<0,05$. Hal ini menunjukkan bahwa Machiavellian berpengaruh signifikan terhadap Persepsi etis mahasiswa akuntansi di Universitas Malikussaleh.

3. Nilai $F_{\text {hitung }}$ sebesar 14,053 . sedangkan $\mathrm{F}_{\text {tabel }}$ pada tingkat kepercayaan $100 \%$ diperoleh $\mathrm{F}_{\text {tabel }(\mathrm{df} 2=\mathrm{n}-\mathrm{k}-1,5 \%)}=3,11$, atau dengan kata lain $\mathrm{F}_{\text {hitung }}>\mathrm{F}_{\text {tabel }}$. Dan juga dapat dilihat dari sig $0,000<0,05$.
Pengujian hipotesis dengan uji F dilakukan dengan membandingkan antara $F_{\text {hitung }}$ dengan $F_{\text {tabel }}$, dan nilai signifikansinya. Dengan demikian berarti secara simultan variabel Love of money $\left(\mathrm{X}_{1}\right)$, dan Machiavellian $\left(\mathrm{X}_{2}\right)$, berpengaruh secara signifikan terhadap Persepsi etis (Y) pada mahasiswa akuntansi di Universitas Malikussaleh.

\section{Keterbatasan penelitian}

Penelitian ini memiliki beberapa keterbatasan yang dapat mempengaruhi hasil penelitian. Keterbatasan hasil penelitian tersebut antara lain :

1. Responden pada penelitian ini hanya sebatas mahasiswa akuntansi di universitas Malikussaleh.

2. Variabel yang digunakan dalam penelitian ini hanya love of money dan Machiavellian.

\section{Saran}

Berdasarkan hasil pembahasan dan kesimpulan mengenai pengaruh Love of money dan Machiavellian terhadap Persepsi Etis Mahasiswa Akuntansi Universitas Malikussaleh, maka saran yang dapat dikemukakan sebagai berikut:

1. Bagi subjek penelitian (Mahasiswa Akuntansi Universitas Malikussaleh)

Adapun saran untuk subjek penelitian saya adalah sebaiknya mendalami sifatsifat yang etis, seperti jujur dalam melakukan hal apa saja yang dapat merugikan orang lain, dan tidak semena-mena dalam membuat perubahan yang tidak sesuai dengan kode etik. Dan mahasiswa harus menghindari sifat dan perilaku yang tidak etis karena seorang akuntan dan auditor merupakan tenaga kerja yang mengandalkan kepercayaan masyarakat. 
2. Bagi Akademis/Fakultas

Berdasarkan hasil penelitian, pengetahuan etika membuat mahasiswa lebih berperilaku etis, sehingga mehasiswa dapat memahami secara jelas apa yang lebih berperilaku etis, dan dalam mengembangkan itu maka MK etika harus diselipkan pada kurikulum etika dan agama.

3. Bagi Peneliti selanjutnya

a. Periode penelitian dapat diperluas lagi penyebaran kuesionernya pada mahasiswa maupun auditor.

b. Pada penelitian-penelitian mendatang disarankan untuk dilakukan pengujian ulang terhadap model penelitian ini dengan menambahkan variabel-variabel lain dan ruang lingkup yang lebih luas, agar dapat diperoleh hasil penelitian yang lebih baik seperti variabel Lucos Of Countrol, Disfungtional Behaior, gender, dan lain-lain.

c. Dan utuk penelitian selanjutnya pernyataan kuesioner sebaiknya diperbanyak lagi agar lebih mudah dalam memahami jawaban dari responden.

\section{Daftar Pustaka}

Al. Haryono Jusup. (2010). Pengauditan. Yogyakarta:Sekolah Tinggi Ilmu Ekonomi YKPN.

Aziz, Toriq Ibnu. 2015. "Pengaruh Love Of Money Dan Machiavellian terhadap Persepsi Etis Mahasiswa Akuntansi”. Yogyakarta Journal of Accounting, Jurnal Nominal/Volume IV Nomor 2.

Arens, A., Elder, R. J., Beasley, M. S., \& J., A. A. (2012). Jasa Audit dan Assurance: Pendekatan Terpadu (Adaptasi Indonesia), Jilid 1. Jakarta: Salemba Empat.

Achmadi dan Narbuko,2009. Metodelogi Penelitian. Jakarta: Bumi Aksara.
Alimul Hidayat, Aziz. 2009. Metode Penelitian Keperawatan dan Teknik Analisis Data. Jakarta: Salemba Medika

Astutik, Menik Puji.2016."Faktor-Faktor Yang Mempengaruhi Sikap Etis Mahasiswa Akuntansi”. Jurnal Universitas Dian Diswantoro.

Bachtiar, Emil. 2012. Kasus-Kasus Etika Bisnis dan Profesi. Jakarta : Salemba Empat.

Berliana Normadewi. (2012). “Analisis Pengaruh Jenis Kelamin dan Tingkat Pendidikan terhadap Persepsi Etis Mahasiswa Akuntansi dengan Love of Money Sebagai Variabel Intervening". Undergraduate. Universitas Diponegoro.

Bertens, K. (2007). Etika. Jakarta: Gramedia Pustaka Utama.

Chaplin, C. P. 1995. "Kamus Lengkap Psikologi”. Cetakan ketiga, diterjemahkan oleh Kartini Kartono. Jakarta: PT Raja Grafindo Persada.

Chiu, R.K.. (2003). “Income Money Ethic, Pay, Satisfaction, Commitment, and Unethical Behaviour: Is the Love of Money The Root of Evil for Hongkong Employees ?", Journal Business Ethic, Vol. 46, pp. 542-8.

Chaplin, J.P.. 2011. Kamus Lengkap

Psikologi. Jakarta: Rajagrafindo Persada.

Charismawati, C.D. 2011. "Analisis

Hubungan antara Love of Money dengan Persepsi Etika Mahasiswa Akuntansi”".

Skripsi Akuntansi Universitas Diponegoro.

Darwati, Yuli. "Keterlambatan Mahasiswa dalam Studi Ditinjau dari Teori Atribusi dari Weiner (Upaya Mencari Solusi atas 
Keterlambatan Mahasiswa dalam Studi di Prodi Psikologi Islam STAIN Kediri)". UNIVERSUM, Vol. 9 No. 1. 2015.

Elias, R. Z. Dan Farag, M. S. (2010)."The Relationship Between Accounting Students' Love Of Money And Their Ethical Perception", Managerial Auditing Journal, Vol. 25 Iss: 3, pp. $269-281$.

Elias, Rafik Z. "The Impact of Machiavellianism and Opportunism on Business Students' Love of Money". Southwestern Business Administration Journal, ISSN: 1554-7892, Vol. 13, pp. 1-22. 2009.

Emzir, 2010. Metodelogi Peneliian Pendikikan:Kuantitatif dan Kualitatif. Jakarta: Rajawali Pers.

Farhan, D. (2012). Etika dan Akuntabilitas Profesi Akuntan Publik. Jakarta: Inti Media.

Fahrianta, R.W. dan I. Ghozali. 2002. Pengaruh Tidak Langsung Sistem Penganggaran Terhadap Kinerja Manajerial: Motivasi Sebagai Variabel Intervening. Jurnal Riset Akuntansi, Manajemen dan Ekonomi. Vol II (1). Februari: 77-113.

Ghozali, Imam. Aplikasi Analisis Multivariate dengan Program IBM SPSS 21 Update PLS Regresi. Edisi 7. Semarang: Badan Penerbit Universitas Diponegoro. 2013.

Gosh dan Crain. 1996. "Experimental Investigation of Ethical Standart and Perceived Probability on International Noncompliance". Behavior Research in Accounting 8.
Harun, Ferawati. "Pengaruh Sifat Machiavellian Dan Love Of Money Terhadap Perilaku Etis Auditor". Makassar Journal Of Accounting, Skripsi: 2016.

Haritsah, Zein, Hendra Gunawan, dan Pupung Purnamasari. "Pengaruh Profesionalisme, dan Sifat Machiavellian Terhadap Pengambilan Keputusan Etis Auditor (Survey pada Kantor Akuntan Publik di Kota Bandung, Jawa Barat)". Prosiding Penelitian SPeSIA. 2015.

Heider, Fritz, Luthans. 2005.

ThePpsychology of Interpersonal Relations, New York: Wiley.

Hoesada, Jan. 2002. "Glosarium Keuangan". Yayasan Obor Indonesia.

http://e-journal.ujay.ac.id (06-November2017)

https://Artikata.com>arti-111062machiavellianism.html (08November-2017)

https://scholar.google.co.id/citations?user=U HdwyF0AAAAJ\&hl=id(27-Maret-2018)

IAPI. Kode Etik Profesi Akuntan Publik Indonesia. 2008.

Ivancevich, John M, Robert Konopaske, dan Michael T. Matteson. Perilaku dan Manajemen Organisasi. Edisi Ketujuh. Jilid 1. Jakarta: Erlangga. 2007.

Indriantoro, Nur, dan Bambang Supomo. Metodologi Penelitian Bisnis Untuk Akuntansi dan Manajemen. Edisi Pertama. Cetakan Keenam. Yogyakarta: BPFE. 2014

Kotler, Philip \& Gary Amstrong. (2011). Principle of Marketing, 10th Edition/International Edition. New Jersey; Prentice Hall 
Luna-Arocas, R. and Tang, T.L.P. (2004), "The love of money, satisfaction, and the protestant work ethic: money profiles among university professors in the USA and Spain", Journal of Business Ethics, Vol. 50, pp. 329-54

Pradanti, Noviani Rindar, dan Andri Pratiwi "Analisis Pengaruh Love of Money terhadap Persepsi Etis Mahasiswa Akuntansi". Diponegoro Journal of Accounting, ISSN: 2337-3792, Vol. 3, No. 3, h. 1-12. 2014.

Lubis, Arfan Ikhsan. Akuntansi

Keperilakuan. Edisi 2. Jakarta: Salemba Empat. 2010.

Maslow, Abraham H,. 2010. Motivation and Personality, Happer \&Row Publisher. New York.

Muchlis, Mustakim. "Pertimbangan Etis, Perilaku Machiavellian dan Gender Pengaruhnya terhadap Pengambilan Keputusan Etis". ASSETS, Volume 2, Nomor 1. 2012.

Mitchell, B.B, Setiawan dan Dwita Hadi Rahmi, 2008. "Pengelolaan Sumber Daya Manusia". Terjemahan, Cetakan Pertama. Yogyakarta : Gajah Mada University Press.

Mowday R, Porter L, Steers R, 1982. "Empoyee-organization Hnkages In P.Warr (Ed.), Organization, and occupational psychology. New York :Academic Press, pp.

Nida, Desak Ruric Pradnya Paramitha. "Pengaruh Persaingan, Pemberian Jasa Lain, dan Sifat Machiavellian pada Independensi Auditor". EJurnal Akuntansi Universitas Udayana 7.3. ISSN: 2302-8556, h. 778-790. 2014.
Pradanti, Noviani Rindar, dan Andri Prastiwi. "Analisis Pengaruh Love of Money terhadap Persepsi Etis Mahasiswa Akuntansi". Diponegoro Journal of Accounting, ISSN: 2337-3792, Vol. 3, No. 3, h. 112. 2014.

Purnamasari, St. Vena, dan Agoes Advensia Chrismastuti. "Dampak Renforcement Contigency terhadap Hubungan Sifat Machiavellian dan Perkembangan Moral". Simposium Nasional Akuntansi 9, Agustus, Padang. 2006.

Puspitasari, Winda. "Sifat Machiavellian dan Pertimbangan Etis: Anteseden Independensi dan Perilaku Etis Auditor". Artikel Ilmiah, Sekolah Tinggi Ilmu Ekomoni Perbanas. 2012.

Prabowo, Damar Septa (2012), “Analisis Pengaruh Paham Machiavellian dan Aspek Love Of Money Terhadap Persepsi Etis Mahasiswa Akuntansi Tingkat Akhir". Semarang.

Richmond, Kelly Ann. (2001). "Ethical Reasoning, Machiavellian Behavior, and Gender: the Impact on Accounting Students' Ethical Deci sion Making". Dissertition.Virginia Polytechnic Institute.

Robbins, S. P., \& Judge, T. A. (2007). Organizational Behavior. 13th Edition. US: Prentice Hall.

Sari, Elsa Vosva.2015.'Pengaruh Sifat Machiavellian dan Perkembangan Moral Terhadap Dysfungsitional Behavioral”. Jurnal Universitas Yogyakarta.

Saputri, IG Agung Yuli, dan Dewa Gede Wirama. "Pengaruh Sifat Machiavellian dan Tipe Kepribadian pada Perilaku Disfungsional Auditor". E- 
Jurnal Akuntansi Universitas Udayana. ISSN: 2302-8556, Vol. 13, No. 2, h. 778-790. 2015.

Sugiyono. (2012). Metode Penelitian

Bisnis. Bandung: CV Alfabeta.

Suliani, Metta, dan Marsono. "Pengaruh Pertimbanagan Etis, Perilaku Machiavellian, dan Gender dalam Pembuatan Keputusan Etis Mahasiswa S1 Akuntansi". Jurnal Akuntansi dan Auditing, Vol. 7, No. 1, November, h. 62-79. 2010.

Tang, T.L.P., Tang T.L.N., and Homaifar, B.Y. (2006), "Income, the love of money, pay comparison, and pay satisfaction, Race and gender as moderators", Journal of Managerial PsychologyVol. 21 No. 5, pp. 476-491.

Tang, T.L.P. and Chen,Y.J. (2008). "Inteleligence vs Wisdom: The love of Money, Machiavellianism and Unethecial Behavior Across College Major and Gender". Journal of Business And Ethic, Vol 82, pp. 1-26.

Widyaningrum Ayu, Triyana, dan Aria Eddy Sarwono. "Analisis Sifat Machiavellian dan Pembelajaran Etika terhadap Sikap Etis Akuntan dan Mahasiswa Akuntan". Jurnal Akuntansi dan Sistem Teknologi Informasi, Vol. 9, No. 1,

Oktober, h. 65-75. 2012.

Wakefield, Robin L. "Accounting and Machiavellianism". Behavioral Research in Accounting, Volume 20, Number 1, h. 115129. 2007.

Yamane, Taro (1967).Statitics An Introductory Analysis 2 Edition. New York. Harper Publisher.
Yuliana, dan Nur Cahyonowati. "Analisis Pengaruh Persepsi Pentingnya Etika dan Tanggung Jawab Sosial, Sifat Machiavellian, dan Keputusan Etis terhadap Niat Berpartisipasi dalam Penghindaran Pajak (Studi Empiris pada Konsultan Pajak di Semarang)". Diponegoro Journal of Accounting, Volume 1, No. 1, 2012.

Yosephus, L. Sinuor. 2010. Etika Bisnis :

Pendekatan Filsafat Moral

Terhadap Perilaku Pebisnis Kontemporer. Jakarta : Yayasan Pustaka Obor Indonesia.

Yeltsinta, Ratih, dan Fuad. "Love of Money, Ethical Reasoning, Machiavellian, Questionable Actions: The Impact on Accounting Students' Ethical Decision Making by Gender Moderation". Diponegoro Journal of Accounting, ISSN: 2337-3806, Volume 2, No. 3, h. 1-11. 2013. 
